International Journal of Social Science (IJSS)

Vol.1 No.2 August 2021, pp: 93-100

ISSN: 2798-3463 (Printed) | 2798-4079 (Online)

DOI: https://doi.org/10.53625/ijss.v1i2.141

\title{
MATIC IMPLICATIONS OF SUNDANESE PUPUH SONG IN BUILDING MORAL VALUES TOWARD ELEMENTARY SCHOOL STUDENTS
}

\author{
By \\ Solihin Ichas Hamid ${ }^{1}$, Tuti Istianti ${ }^{2}$ \\ ${ }^{1}$ Lecturer of Civics Education at UPI in Cibiru \\ Kania Siti Nurjannah, S.Pd. / Gilang Tresna Nopitasari, S.Pd. \\ ${ }^{2}$ Teachers of 4 - 5 Grade at SD Negeri Citeureup Mandiri 3 Kota Cimahi \\ Email: solihin.ichas@upi.edu
}

\begin{tabular}{l}
\hline \hline Article Info \\
\hline Article history: \\
Received May 4, 2021 \\
Revised June 27, 2021 \\
Accepted July 16, 2021 \\
\hline
\end{tabular}

Keywords:

Matic-Implication

Traditional Song

Pupuh Sunda Song

Ethno-Pedagogic

Medium is Massage

\begin{abstract}
The title above has explained the purpose of this study, which is observing Matic's implication of children's moral values acquisition from learning activities to sing Pupuh Sunda Song in Elementary Schools - West Java. The methodology used is ethno-pedagogic because the extent of data collection and exploration were conducted toward the concept containing values that existed and lived amid the society within the context of ethnic tradition, that is, as far as signs and meanings are stored and expressed in vocal art expressions in the form of Pupuh Sunda song acted as a medium is message education praxis. Therefore, the phenomenology approach was carried out to observe a series of phenomena that can be analyzed during the concept values repeated into the performer's subconscious, the song, movements, and expressions in shared or personal situations. The stressing keyword point in this study is the repetition that can be assumed as a mechanical act on every subject learn to sing moral message content sung. The mechanical process activities result by repeating song memorization, expressing moral values inside the song. Qualitatively, it can be described as an automatic implication that has the potential and function as a fostering for the concept of value in building the expected character. Such as the direct utterance stored in the song containing the invitation and teaching always to be cheerful, accept everything with generosity, care to all being (compassionate), diligent in studying and fond of working, respecting the parents and teachers, love to the homeland and defending the state and nations, which becomes the focus of study.
\end{abstract}

This is an open access article under the CC BY-SA license.

Corresponding Author:

Solihin Ichas Hamid

Lecturer of Civics Education at UPI in Cibiru

Email: solihin.ichas@upi.edu

\section{INTRODUCTION}

Instilling moral values as educational efforts, regarding building the attitude that will become the foundation of human behavior, is not an instant activity that its outcome quality can be soon apparent, but it is still possible. The challenging and indirect educational outcome relating to the foundation of building behavior, no doubt, causes the notion of accepting and agreeing to instill moral values in its praxis to become minimal. Because it grounds on the

Journal homepage: https://bajangjournal.com/index.php/IJSS 
rationalization that establishing moral attitude option which must be given to children is the achievement of a long journey.

Since the beginning of the birth of humankind, from ancient times until modern times today, civilization and culture grow and develop to provide direction on life awareness and goals, whether it be a pleasure, victory to happiness in tranquility- were open becoming options, constantly changing. Because life is always like it started yesterday, lived now to meet tomorrow. Education is as old as life itself and teaches noble attainment rather than satisfying animal desires; therefore, morals are taught in different ethnic views and sacred impressions.

In ancient life tradition, it is said that the chanting of tones and shrill voices has been used as a ritual offering to the worshiped. Therefore, singing and chanting show primeval traces as an educational tool in delivering humankind's survival to recognize their life purposes. Except it becomes the expressive part in religious ritual in the ancient times, becomes war encouragement until mischief act conducted to a fellow human. As an instrument, singing and music that accompanies when injustice reigns are not sinful, but who is the mastermind behind that wickedness. Hence, throughout political history, numerous songs or anthems were forbidden by the authority in the past.

For education, if the education itself in its station as an instrument is not free of value, it is bound by the noble purpose of celebrating life and humanity. If in the implicit meaning of education contains the fundamental noble values which becomes the life of humankind, so, the chanting of the song from wherever it comes and in whatever language it sounds, it is moral teaching, guidance to do good deeds, it has to be preserved as a cultural product protecting civilization.

\section{A. The focus of Problems and Research Objectives}

Based on the above background, the focus of problems in this research is formulated in the following statement:

1. How can the infusing of moral value concepts be carried out in learning Sundanese Pupuh songs on Elementary Schools students in West Java?

2. How the Art Matic-Implication of Sundanese Pupuh song in Building Moral Values toward Elementary Schools students in West Java?

\section{LITERATURE}

In the ethnic of Javanese, Sundanese, Balinese, or other Archipelago ethnical units, people inherit various art cultures whose signs and traces still live. However, it is starting to fade compared to the enlivening and celebrated art born out from the globalization supported by information technology modernization and post-modernism in the $21^{\text {st }}$ century. Among the traditional arts that still impressively attract global attention, including in the country, are various forms of art that are exotically marked the opposite of modern product and activity performances. The traditional art genres mark the Archipelago Diversity in Java and Bali, including in West Java land, Sunda culture. In the context of educational interests, primarily related to shaping Nation's Character Building, one of which is vocal art. Why is Vocal art the choice? The art of movement and the combination between them certainly has the same strong potential, but basically, the vocal art becomes the first tool in touching the literary disclosure. Undoubtedly, literature as the collective ideal of humanity is a place for noble thoughts, values of life, maintaining civilization, and human ideals to be more demanding of the accuracy of chanting songs than the splendor of singing followed by movement of the game.

The name Pupuh itself, although it was local with the characteristics of content, type, and its meaning, was somehow called the same as in Sundanese, Javanese, and Balinese. It is one of the traditional songs known by the elders and teachers in those areas, and it functions as a medium for learning and education in childcare. Moreover, the form of singing combined in the game certainly has a strengthening aspect of being achieved in the totality of education for children, but it was not on the primary elements, e.g., mental building as the fundamental psychological aspects. This study wants to observe in phenomenological how the traditional song, which is called as Pupuh song, with its characteristics properties, can be traced in providing meaning to build child's moral and value attitude existed in the developmental phase during Elementary School. That as far as the writers' concern, it has not been found a profound comparative study yet, but it can be taken quickly to believe; that the song or anthem in traditional tone, whether it be serious or humorous as a widely-open activity for kids, whatever the place is it has a meaning as a learning activity, fulfill their developmental requirements. Hence, singing is a sole activity, and as a part of the game of its characteristics 
International Journal of Social Science (IJSS)

Vol.1 No.2 August 2021, pp: 93-100

ISSN: 2798-3463 (Printed) | 2798-4079 (Online)

DOI: https://doi.org/10.53625/ijss.v1i2.141

and content, as an art product which cannot be separated from its mind's expression, good feelings, and hopes that philosophically reflect the noble beliefs of the supporting community. If the art were stored in the traces and local language, the properties would become a cultural heritage that must be protected as a national root culture and preserved at least as an appreciation media for future generations born in the different lingual environment and atmosphere. Thus, how far the extent of the traditional values can still be meaningful, at least in maintaining synergy of the civilization and culture on the goal of celebrating life and humanity from the threat of being disoriented by the deception of artificial progress, has become an institutional task and an educational, cultural environment that is obliged to carry out its role.

As a knowledge, the anthem called as Pupuh, which discussed in this research, explains: In which as it is in the repertoire of Javanese and Balinese literature, of the 17 Pupuh known, Sundanese language and literature can be distinguished among them, in some Sekar Ageung and Sekar Alit categories. The Sekar Ageung genre that is KSAD is widely known and selected by teachers and schools taught to Elementary School students. In comparison, the remaining 13 genres, including Sekar Alit, were only common knowledge because not all teachers can apply in their lesson. For this reason, as an overview of the overall knowledge for 17 Pupuh songs as seen from the characters content and their form, it is necessary to reveal them in the following table:

Table 1. Character Type (content) and Pupuh 17 Forms / Patterns

\begin{tabular}{|c|c|c|c|}
\hline No & Pupuh Type & $\begin{array}{l}\text { Content Characteristics } \\
\text { (character) }\end{array}$ & Forms / Patterns \\
\hline 1 & Sinom & pleasure and joy or affection & $\begin{array}{l}9 \text { lines : 8-a, 8-i, 8-a, 8-i, 7-i, 8-u, } \\
\text { 7-a, 8-i, 12-a. }\end{array}$ \\
\hline 2 & Dangdanggula & $\begin{array}{l}\text { beauty, pleasure, serenity, } \\
\text { greatness, optimism }\end{array}$ & $\begin{array}{l}10 \text { lines : 10-i, 10-a, 8-é/o, 7-u, 9- } \\
\text { i, 7-a, 6-u, 8-a, 12-i, 7-a. }\end{array}$ \\
\hline 3 & Kinanti & affection, waiting, worry & 6 lines : 8-u, 8-i, 8-a, 8-i, 8-a, 8-i \\
\hline 4 & Asmarandana & $\begin{array}{l}\text { feelings of affection, feelings of } \\
\text { love (beloved), or romance }\end{array}$ & $\begin{array}{l}10 \text { lines : 10-i, 10-a, 8-é/o, 7-u, 9- } \\
\text { i, 7-a, 6-u, 8-a, 12-i, 7-a. }\end{array}$ \\
\hline 5 & Lambang, & $\begin{array}{l}\text { jokes, humors containing lesson } \\
\text { for reflection }\end{array}$ & $\begin{array}{l}6 \text { lines } \\
8-a, 8-a, 8-a, 8-a, 8-a, 8-a .\end{array}$ \\
\hline 6 & Maskumambang & $\begin{array}{l}\text { the character of concern, sadness, } \\
\text { or heartache }\end{array}$ & 4 lines : 12-i, 6-a, 8-i, 8-a. \\
\hline 7 & Pucung & angry with oneself & 4 lines: 12-u, 6-a, 8-é/o, 12-a. \\
\hline 8 & Ladrang & jokes, humor with satirical intent & $\begin{array}{l}5 \text { lines : } \\
10-\mathrm{i}, 4-\mathrm{a}(2 \mathrm{x}), 8-\mathrm{i}, 12-\mathrm{a} \\
\end{array}$ \\
\hline 9 & Balakbak & jokes, comedy, daily humor. & 3 lines: 15-é, 15-é, 15-é. \\
\hline 10 & Pangkur & $\begin{array}{l}\text { Feeling upset, anger buried within } \\
\text { one's heart because of the heavy } \\
\text { burden of jobs. }\end{array}$ & $\begin{array}{l}7 \text { lines : 8-a, 11-i, 8-u, 7-a, 12-u, } \\
\text { 8-a, 8-i. }\end{array}$ \\
\hline 11 & Magatru & $\begin{array}{l}\text { Feeling sad, disappointment, } \\
\text { regret to oneself }\end{array}$ & 5 lines : 12-u, 8-i, 8-u, 8-i, 8-o \\
\hline 12 & Juru Demung & $\begin{array}{l}\text { Confused, difficulty dealing with } \\
\text { work }\end{array}$ & $\begin{array}{l}8 \text { lines : 8-a, 8-u, 8-u, 6-i, 4-i, 6-i, } \\
\text { 8-a, 8-u. }\end{array}$ \\
\hline 13 & Mijil & Feeling sad but full of hope. & $\begin{array}{l}6 \text { lines : 10-i, 6-o, 10-é, 10-i, 6-i, } \\
\text { 6-u. }\end{array}$ \\
\hline 14 & Wirangrong & Feeling ashamed toward oneself. & $\begin{array}{l}6 \text { lines : 8-i, 8-o, 8-u, 8-i, 8-a, 8- } \\
\text { a. }\end{array}$ \\
\hline 15 & Gurisa & $\begin{array}{l}\text { daydreaming, fantasizing about } \\
\text { something empty }\end{array}$ & $\begin{array}{l}8 \text { lines : 8-a, 8-a, 8-a, 8-a, 8-a, 8- } \\
\text { a, 8-a, 8-a. }\end{array}$ \\
\hline
\end{tabular}




\begin{tabular}{|c|l|l|l|}
\hline 16 & Gambuh & $\begin{array}{l}\text { Sadness, heartbroken, dealing with } \\
\text { difficulty }\end{array}$ & lines : 7-u, 10-u, 12-i, 8-u, 8-o. \\
\hline 17 & Durma & Excited, angry or elate & $\begin{array}{l}\text { 7 lines : 12-a, 7-i, 6-a, 7-a, 8-i, 5- } \\
\text { a, 7-i. }\end{array}$ \\
\hline
\end{tabular}

Based on the identification of Pupuh (rumpaka) lyric, it can be categorized as a simple song because the word uttered refer to the direct meaning which can be understood its intention - unsymbolic and heavily poetic. However, it is a severe song (Daria) whose standard rhyme can be easily imitated, so that it creates challenges in the learning praxis.

The seventeenth Pupuh songs are in the form of expression that sings the mood, such as cheerful, upset, ashamed, full of hope and love, entirely invitation and teaching to do good deeds as a child to their peers, respecting parents et cetera. The problem is, Pupuh song is the legacy of the old days, no longer as lively as it was in the days of our parents - in the early days and before independence. With the current social, linguistic situation, the limitations of schools and resources as a negative reality, the advantage of the current technological progress facility can be maximized to animated the weak, especially if the two different generations, the middle generation, can be able to be weak a connector for differences.

\section{RESEARCH METHOD}

The methodology used in this study is called ethno-pedagogic because it tries to observe educational praxis from the perspective of system values and local wisdom that existed within the Sundanese ethnic, cultural tradition. Therefore, the semiotics approach and semantics analysis inside it becomes the option to describe numerous signifiers and the depth of meaning of product instrumentation and cultural arts activities in learning praxis according to the elementary school curriculum. The rest, as the medium is the message of traditional singing, especially the Sundanese Pupuh Song, will be explored as the main instrument (test tool) for fostering the concept of moral values contained in verbal messages content sung in vocal activities, both personal and collective, along with its repetition allowing it to be done almost without border (longitudinal).

\section{RESULTS AND ANALYSIS}

\section{Instilling Moral Values Concept in Learning Sundanese Pupuh Song}

As explained by Elyzabet F.Lyn (1974) in Djahiri Kosasih (1981) Hamid, S Ichas (1984) that "Values and morals cannot be taught, but in other ways." So, it is necessary to approach or learn methods that can resonate with children's affective potential. Because values and morals, although they can understand it conceptually, they still cannot choose to determine their attitude when there is no pre-condition, spiritual environment shaping them. Hence, using the selected media and describing life itself in a story, both delivered orally and visually, can provide a more concrete example than other methods, but it is still exciting, and it is expected to move children's hearts as the pupil. Moreover, other media regarded as enjoying the atmosphere and learning activities are song and anthem.

Utilizing Song and Anthem as a learning medium besides attractive and enjoying provides expressive space for students' affective potential when the child does learning activity, a standard or reference they must follow as in scales and harmonies. Its actualization is an area of artistic intelligence. As a result, the song and anthem also consist of verbal expression, meaning, and significance, both direct and hidden.

For children, verbal utterance with direct meaning in a traditional game song surely more appropriate to be used as a learning medium than symbolism approach. However, a song full of cheerful movements-separated from its content and words-is truly accommodative for children, and seeing from their requirement to play and learn that are motorized and laughter in happy songs together are thematic.

The song genre in which its verbal expression is direct is found in Pupuh songs, particularly the Pupuh, which is designed and regarded as appropriate for children's education. Out of 17 Pupuh types referred to as the learning media in Elementary School were known as the minimal KSAD (Kinanti, Sinom, Asmarandana, and Dangdanggula) abbreviation; thus, it depends on teacher's readiness, it is also possible by adding other types that are considered appropriate to the child's world, such as Pucung, Balakbak, Magatru, pangkur. However, it can also be understood 
International Journal of Social Science (IJSS)

Vol.1 No.2 August 2021, pp: 93-100

ISSN: 2798-3463 (Printed) | 2798-4079 (Online)

DOI: https://doi.org/10.53625/ijss.v1i2.141

that, as occurred in the past, if a teacher in Elementary School make limitation and selection because the learning outcome was not the quantity but rather the intensity. It is just that the purpose perspective for developing civics moral values sees it more in the moral message content than as many as 17 Pupuh types.

Nevertheless, the Pupuh song is categorized as a simple hymn if observed based on the lyric content and language used, easily understandable content for children. However, to sing Pupung anthem is not easy for everyone, either for those who are beginning to study or adults, because there is Wirahma's song like the reference; even though it is not easy, it gets exciting when the student can merge in tune with an excellent vocal voice. As a learning medium, the learning outcome target to study Pupuh was not to show off their skill though there is the competition to accommodate their art interest. The objective was instead to introduce local culture variety, and particularly moral values message in the song. Because by repeatedly singing both personally and collectively, the message's content and moral guidance are deposited slowly and repeatedly.

In the following example, it is shown some Pupuh type which can be taken as Medium is Message fulfilling content and scope of learning regarding Civics Moral Values development which potentially can be instilled toward students in Elementary School.

Table 2. Pupuh instances which the content meet Moral Values development in Civics subject in Elementary School

\begin{tabular}{|c|c|c|c|c|}
\hline No & Type & Example of Content & Meaning & Character \\
\hline 1 & Pucung & $\begin{array}{l}\text { Utamana jalma kudu rea } \\
\text { batur / keur silih tulungan / } \\
\text { Silih titipkeun nya diri / Budi } \\
\text { akal lantaran ti pada jalma }\end{array}$ & $\begin{array}{l}\text { The utmost we have to had } \\
\text { many friends to help each other } \\
\text { / care to each other/common } \\
\text { sense is from each other }\end{array}$ & $\begin{array}{l}\text { Social } \\
\text { Attitude }\end{array}$ \\
\hline 2 & $\begin{array}{l}\text { Wirang } \\
\text { rong }\end{array}$ & $\begin{array}{l}\text { Barudak mangka ngalarti / } \\
\text { Ulah rék kadalon-dalon / } \\
\text { Enggon-enggon nungtut élmu } \\
\text { /Mangka getol mangka tigin / } \\
\text { Pibekeleun saréréa / Modal } \\
\text { bakti ka nagara }\end{array}$ & $\begin{array}{l}\text { You must understand, do not be } \\
\text { careless, in studying, must be } \\
\text { diligent and tenacious, } \\
\text { provision for all, in order to } \\
\text { serve the country }\end{array}$ & $\begin{array}{l}\text { Self- } \\
\text { discipline }\end{array}$ \\
\hline 3 & Durma & $\begin{array}{l}\text { Moal ngejat sanajan ukur } \\
\text { satapak / Geus dipasti ku } \\
\text { jangji / Mun tacan laksana / } \\
\text { Numpes musuh sarakah / } \\
\text { Heunteu niat seja balik / } \\
\text { Najan palastra / Mati di } \\
\text { medan jurit }\end{array}$ & $\begin{array}{l}\text { Will not step back, fulfill the } \\
\text { promise is inevitable, and crush } \\
\text { the enemy if it has not been } \\
\text { carried out. } \\
\text { No intention to go back, There } \\
\text { is no intention of returning, } \\
\text { even if I have to risk my life, I } \\
\text { will die on the battlefield }\end{array}$ & $\begin{array}{l}\text { Passion for } \\
\text { defending } \\
\text { the nation }\end{array}$ \\
\hline 4 & $\begin{array}{l}\text { Dangdang } \\
\text { gula }\end{array}$ & $\begin{array}{l}\text { Lambang RI / Jero ngandung } \\
\text { harti / Lamun bener di } \\
\text { amalkeunna/ } \\
\text { Persatuan tangtu tembong / } \\
\text { Teu cukup ku di sebut/ } \\
\text { Atawa apalna biwir/ Bhineka } \\
\text { tunggal ika/ Maksudna } \\
\text { gumulung'/ Kabeh seler-seler } \\
\text { bangsa beda-beda /Tatapi } \\
\text { asal sagetih / Tapi sa asal } \\
\text { Hiji basa Hiji bangsa/ } \\
\text { Basa bangsa indonesia } \\
\text { Hiji bangsa Hiji nusa } \\
\text { Nusa tunggal nusantara } \\
\text { Seler-seler suku bangsa Ti } \\
\text { wewengkon mana mana / } \\
\text { Saka suka saka duka }\end{array}$ & $\begin{array}{l}\text { The symbol of R.I contains a } \\
\text { profound meaning, if it were } \\
\text { practiced sincerely, the union } \\
\text { would be created, it is not only } \\
\text { just by saying, or lip service, } \\
\text { Bhineka Tunggal Ika, it means } \\
\text { to be united, all the children of } \\
\text { the nation even though they are } \\
\text { different, but from blood, one } \\
\text { origin } \\
\text { One language, one nation, the } \\
\text { Indonesian language. One } \\
\text { nation, one Archipelago, Nusa, } \\
\text { the Archipelago. Each ethnic } \\
\text { unit from a different region } \\
\text { unite in joy and suffering }\end{array}$ & $\begin{array}{l}\text { Unity } \\
\text { Symbol }\end{array}$ \\
\hline
\end{tabular}




\section{Matic Implication of Sundanese Pupuh Art Song in Building Elementary School Children's Moral Values Attitude}

As typical songs and anthems, if it was not for the beauty of the words, it is undoubtedly for the song's composition. If the song is good, a simple rhyme will be easily understood by people to express their mood or to fulfill leisure time. Similarly with a good rhyme or even a funny rhyme will easily attract to be expressed, imitated, with or without song. Teachers' educational songs will become "homework" automatically because the song obtained in the school either from teachers or friends in a game will be a good lesson for children once they were at home.

Pupuh song formally taught at school, as an art lesson activity, will be interesting, challenging for children always to repeat the song on many occasions. Vocal and song repetition of the game will be repeated continuously during the child's development stage. It truly has automatic implications on fostering moral messages and values that verbally expressed and symbolic movement conducted by children from time to time.

If it was not by automatic mechanic repetition, like water that is rotated using the electric motor, there is no way that the water spewed out by the suction machine has undergone a filtering process, so of course, there has been a difference compared to the input before entering the filter machine. In the limitation and capacity, the filtering machine has worked. Likewise, as in material art, an auto mechanic function can help dissolve residue to control the pool's water quality. Education is a complicated matter that is not as simple as engineering the movement of materials. Moreover, psychological matters are not merely aspects of the ability to master knowledge but morals as the expected standard of behavior. Although it can be simplified to be limited to civics morals, psychological matter that the actualization of behavioral values in social relations as citizens is pragmatic. There are no other reliable ways as in the method to increase mathematical or science problem-solving questions in Educational practice.

Therefore, the effort to achieve learning which aims to build morale as human (as a subject) behavioral standard control must be made, the first, it is not how, but rather where to start, and second, it is not to maximize outside strength, but to enliven mechanical ware which can run by itself - without force. This automatic is intended in the study, Matic-implication of Sundanese Pupuh song activity as the instrument to foster moral values in elementary school children. It is expected no longer as conceptual knowledge, but it merges within the conscious potential as a repetition intention effect that could be unlimited if the approach to study vocal art instrumentally also instills children's appreciative ability.

\section{Research Result}

As an implementation activity of the limited-term model, this study is not sufficiently competent to observe downstream results, e.g., the apparent attitude changes of students who become the subject immediately after the learning process are completed. Nevertheless, the study prefers to observe the mechanical traces of learning activities conducted repeatedly and in the long-term by the students. The method is possible because the art product potential will fulfill the function as a Medium is Ma\#ssage with longitudinal traits. Hence, it conforms to the formulation of problems and findings in this research. As far as the successful implementation of the learning model for civic moral values through singing Pupuh songs in elementary schools, it can be described: 1) The teachers have carried out curricular tasks conforming to the 2013 curriculum in elementary schools, that is, carrying out learning with a thematic approach, regarding the development of Civics Literacy based on local traditions, so that the achievements of the Civics Elementary School subject as the Core curriculum can be developed more articulately and creatively by merging other subjects whose content is based on integrated arts, literature, and local culture; 2). Elementary school students, both in normal situations and coincidentally, when the study activities were carried out, we are in a reasonably long pandemic situation, did not experience significant obstacles. Because learning the Sundanese Pupuh Song as a vocal art activity can be done in various ways, including online media. Afterward, suppose in the other subject learning activities, the students can get easily bored. It is different when studying Vocal art activity in which its content is full of knowledge and appreciating literature and local culture and moral message explicitly mentioned as the Core Curriculum, e.g., Civics learning outcome in Elementary School; 3). In a cheerful learning situation, it can be created by the teacher and its implication to the student, because learning content of Sunda art song as one of the regional cultural heritage has instrumental power as the media of learning the art (aesthetic): vocal and musical, literature and language and moral teaching (ethic) which indirect because it just as a reminder (engaging). 
International Journal of Social Science (IJSS)

Vol.1 No.2 August 2021, pp: 93-100

ISSN: 2798-3463 (Printed) | 2798-4079 (Online)

DOI: https://doi.org/10.53625/ijss.v1i2.141

\section{CONCLUSION}

Based on the above findings, the study draws the following conclusions, among others are:

1. The activity of learning Sundanese Pupuh art song conforms to the school curriculum. The content is vocal and singing technical learning (Ngawih) and fulfilling the function of the introduction, strengthening special interests and students' appreciation of the richness of regional arts and culture in MP SBdP. The perspective of Pancasila and Civics Education can function as a medium for seeding value concepts and growing attitudes morals for elementary school-age children.

2. The repetition process in the learning activity and art song appreciation conducted by children is started with teacher's guidance, parents, until by itself they will repeat individually and collectively with their peers, has the potential to be an incubator for fostering the concept of values and morals which becomes the song's message contents (kawih)

\section{REFERENCES}

[1] Abdillah, F., Hamid, S. I., \& Istianti, T. (2017). Ethnic Idiom Articulation and Civic Education Material for Elementary School - Development of Cultural Citizenship Literacy. 1st International Conference on Educational Sciences - ICES (pp. 225-229). Bandung: ScitePress.

[2] Alif, Zaini., (2013) Pendidikan Karakter dalam Mainan dan Permainan Tradisional Jawa Barat, Pemerintah Propinsi Jawa Barat

[3] Docherty, I., Goodlad, R., \& Paddison, R. (2001). Civic Culture, Community and Citizen Participation in Contrasting Neighbourhoods. Urban Studies, 38(12), 2225-2250

[4] Duncker, K. (2015). Cultural citizenship: Understanding the natural states of freedom participation and equality in light of societies self-awareness, -contemplation, and -reflection through culture and cultural evolutionary learning by mode of media. Florence: European University Institute.

[5] Hlepas, N. (2013). Cultural Diversity and National Performance. . Athens, Greece: International Centre for Black Sea Studies (ICBSS).

[6] Hamid, S.I., \& Istianti, T. (2012). Rekonstruksi Nilai Moral Kewarganegaraan Berdasar Analisis Semantik Terhadap Ungkapan Kultural Masyarakat Sunda. Cakrawala Dini: Jurnal Pendidikan Anak Usia Dini, 3(2).

[7] Hamid, S. I. (2015). Nilai Moral Kewarganegaraan Dalam Artefak Kehidupan Sosial Kultural Masyarakat Sunda: Studi Eksploratif Nilai Moral Kewarganegaraan dalam Ungkapan, Artikulasi Seni dan Ritual Adat Budaya Sunda. . Universitas Pendidikan Indonesia, Pendidikan Kewarganegaraan. Bandung: Sekolah Pascasarjana.

[8] Hamid, S.I. (2015). Semiotika Pendidikan Kewarganegaraan dalam Tradisi Lokal Sunda. . Bandung: Rizqi Press.

[9] Hamid, S.I. (2016). A Description of Citizenship Moral Values in Sundanese Society. Man In India, 96(12), 51255141.

[10] Hamid, S.I, (2017), Pendidikan Kewarganegaraan dalam Semiotika Sunda, Bandung, Cetakan ke 2. Rizqi Press.

[11] Hamid, S.I, (2017) A. Description of Citizenship Moral Values In Sundanese Society, @ Serials Publications Ma In India, 96 (12): 5125 - 5141

[12] Hamid, S. Ichas, Istianti, Tuti \& Abdillah, Fauzi, Firmansyah, Ferri Hidayatullah; (2019) : The Indonesian Proverb Of Peace: Educational Semiotics Analysis For

[13] Hamid, S. I., \& Istianti, T. (2018). Pengembangan Pembelajaran PPKn di SD-MI. Bandung: UPI Kampus Cibiru.

[14] Hamid, S I., Istianti, T., \& Abdillah, F. (2019). Mengurai Konstelasi Filosofis Pancasila melalui Literasi Budaya Kewarganegaraan dan Literasi Digital Kewarganegaraan. Prosiding Seminar Pendidikan Nasional Membangun Pendidikan Berbasis Paradigma Higher Order Thinking Skills dalam Konteks Keindonesiaan (pp. 52-68). Bandung: UPI Kampus Cibiru.

[15]Hamid, S.I; Istianti, Tuti \& Abdillah, Fauzi (2019), Cultural Citizenship Literacy; Proceeding, 4 th ICERD International Conference on Education and Regional Development.

[16]Hamid, S.I; Istianti, Tuti \& Abdillah, Fauzi : (2020) Cultural Citizenship Literacy Learning Model: The Acquaintanceship In An Homogeneous Society, International Journal of Psychosocial Rehabilitation, Vol. 24, Issue 08, 2020 ISSN: 1475-7192 Received: 27 Mar 2020 | Revised: 20 Apr 2020 | Accepted: 05 May 20209104

[17] Miller, T. (2002). Cultural Citizenship. . In E. F. Isin, \& B. Turner, Handbook of Citizenship Studies (pp. 231244). London: Sage Publications Ltd.

[18]Lee, T. (2013). Public Culture and Cultural Citizenship at the Thessaloniki International Film Festival. Cambridge, Massachusetts: Harvard University. 


\section{THIS PAGE HAS INTENTIONALLY BEEN LEFT BLANK}

